\title{
Don Quijote en la guerra del Francés
}

\author{
Ceferino Caro López*
}

La situación política de los primeros años del siglo XIX, con la invasión de la Península y la resistencia a las tropas napoleónicas, marcó en España un clima intelectual en el cual la figura de don Quijote tomaría una función inesperada, puesto que se llegó a usar como instrumento de propaganda bélica. La Guerra del Francés era también una guerra de opinión y no sólo de las armas, y comprometía directamente a todos los grupos sociales y sus intereses, con lo que requería un discurso ideológico específico: por ello «algunos personajes, hablando en nombre propio o como portavoces de alguna entidad colectiva [...] se encarga[ba] $\mathrm{n}$ de explicarles la significación y gravedad del conflicto» a los combatientes salidos del pueblo ${ }^{1}$. En el fondo, se trataba de simple propaganda de guerra, como siempre la había habido, la habría más tarde y la había ya entonces. Las prensas españolas ya habían publicado noticias patrióticas ${ }^{2}$, denuncias de las maniobras

* Madrid.

1. Tales obras políticas, faltas de cualquier valor estético, son manifestaciones de «aspectos ideológicos y el contexto social que refleja[n]», Aymes, Jean-René, «La imagen de Francia y de los franceses en España en 1808», en La Guerra de la Independencia (1808-1814): perspectivas desde Europa, Jaén, Universidad de Jaén, 2002, p. 85. Díaz, Joaquín, «Una tradición subterránea: 1808 en la cultura popular entre siglos», en La Guerra de la Independencia en la cultura española, Joaquín Álvarez Barrientos (ed.), Madrid, Siglo XXI, 2008, pp. 223-238. Para una teoría de la propaganda política, véase Pizarroso Quintero, Alejandro, Historia de la propaganda: notas para un estudio de la

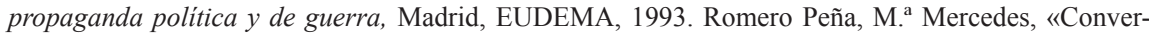
saciones, diálogos y triálogos durante la Guerra de la Independencia española» Revista de Literatura, LXVIII, 136, 2006, pp. 503-520, analiza el esquema compositivo de algunos textos, siempre muy simple, y reseña el Sueño del tío José, la Quema de la Constitución, la Carta a Murat y El don Quijote de Meseguer, de los que más abajo se hablará.

2. Diálogo entre Napoleón y Mina en los campos del honor de Navarra. "“Acción y pasión" frente al insípido racionalismo o la insulsez de las normas obligatorias y, sobre todo, frente al descaro extranjero que ofende a la patria, a la religión y a la mujer propia», dice Díaz, José, «Literatura de 
políticas contra el rey Fernando, como el libro de Cevallos, la Conspiración tramada en España por Buonaparte..., proclamas como el Manifiesto del Consejo Real ${ }^{3}$ para informar, enfervorizar y dirigir al pueblo en armas. Queriendo condenar al Emperador, había aparecido incluso una interpretación del Apocalipsis en la que se lo identificaba con el anticristo y se encontraba que el numero de la Bestia, el 666, era el resultado de sumar el valor de las letras del nombre de Napoleón... ¡ ¡n griego y en italiano! ${ }^{4}$. Que el Emperador fuera lo más parecido al anticristo se afirmaba también en El nuevo don Quijote de Sevilla, donde se le echaba en cara «la dañina intención de $\mathrm{Vd}$. y el odio que parece abriga en su corazón contra el estado religioso», y «el descaro con que Vd. se burla de lo que está aprobado y recibido por la iglesia universal» 5 .

También se había asociado Napoleón a Carlomagno o a Francisco I, destinado como ellos a repetir las derrotas sufridas por aquéllos en España ${ }^{6}$.

Como cabría esperar, no faltaron tampoco los ataques ad personam contra Bonaparte en algo que iba más allá de la crítica política, pero se enmarcaba

cordel: pliegos, aleluyas», en Se hicieron literatos para ser políticos. Cultura y política en la España de Carlos IV y Fernando VII, Joaquín Álvarez Barrientos (ed.), Madrid, 2004, p. 69.

3. Cevallos, Pedro, Exposición de los hechos y maquinaciones que han preparado la usurpación de la corona de España, y los medios que el emperador de los franceses ha puesto en obra para realizarla. Por Don Pedro Cevallos, Primer Secretario de Estado y del Despacho de S.M. Fernando VII, Madrid, Imprenta Real, 1808; Conspiración tramada en España por Buonaparte por medio de algunos generales franceses, y con la ayuda de algunos españoles, indignos de este nombre, Mallorca, Felipe Guasp, 1814 (reimpr.); Noticia de lo ocurrido en la ciudad de Alcalá de Henares, con ocasión de la proclamación hecha por los estudiantes de su universidad, en obsequio de nuestro amado monarca Fernando VII en la noche del 13 de agosto de 1808, Alcalá, Real Universidad, 1808; El filósofo en su quinta o Relación de los principales hechos acontecidos desde la caida de Godoy hasta el ataque de Valencia; Sermón [...] en acción de gracias por la victoria que un solo Batallón de Infantería de las valientes Tropas de S. M. el Sr. D. Fernando VII (que Dios guarde) al mando del Mariscal de Campo D. Juan Martín Diez, el Empecinado, consiguió sobre más de dos mil franceses que le atacaron sobre el Puente de Zulema en la mañana del 22 de mayo de 1813, Alcalá, Manuel Amigo, 1813; Manifiesto de los procedimientos del Consejo Real en los gravísimos sucesos ocurridos desde octubre del año próximo pasado, impreso de orden del mismo Supremo Tribunal, Madrid, Imprenta Real, 1808; El Sueño del Tío José, que quiso ser primero, y quedó cola, y Largo discurso que tuvieron Napoleón y Murat después que regresó éste de España a Francia, Madrid, Repullés, 1808; Carta que un español escribe a Murat sobre sus aventuras en España, reimpreso en la Casa de la Misericordia de Cádiz, s.a.; La quema de la Constitución en Aldea Leal, por el Doctor Don Patricio Español, Valencia, Burguete, 1808; Conversación que tuvo el Príncipe Murat con Don Manuel Godoy, relativa a los sucesos de España, Madrid, Collano, s.a. Véase Romero Peña, op. cit., pp. 503-520. La bibliografía es extensísima: Gómez Imaz, Manuel, «Los periódicos durante la Guerra de la Independencia», Revista de Archivos, Bibliotecas y Museos, Madrid, 1910; Freire López, Ana, Índice bibliográfico de la colección documental del Fraile, Madrid, Servicio Histórico Militar, 1983.

4. He aquí el cálculo: $\mathrm{N}=10, \mathrm{~A}=1, \mathrm{P}=60, \mathrm{O}=50, \mathrm{~L}=20, \mathrm{E}=5, \mathrm{~A}[!]=1, \mathrm{~N}=40, \mathrm{~B}=2, \mathrm{U}=110, \mathrm{O}=50$, $\mathrm{N}=40, \mathrm{~A}=1, \mathrm{P}=60, \mathrm{~A}=1, \mathrm{R}=80, \mathrm{~T}=100, \mathrm{E}=5,=666$. S.G. L. A. DEL S. DE M. N. D. A. La bestia de las siete cabezas y diez cuernos o Napoleón emperador de los franceses. Exposición literal del capítulo XIII del Apocalipsis por un presbitero andaluz, vecino de la ciudad de Málaga. Málaga, Martínez, 1808, pp. 21-21. Cita La bestia como uno de los muchos ejemplos de escritos patrióticos religiosos Alonso, Gregorio, «Del altar una barricada, del santuario una fortaleza», en La Guerra de la Independencia en la cultura española, op. cit., pp. 91-92.

5. F. J. A. R. d. L. T. El nuevo don Quijote de Sevilla, 2, Sevilla, Imprenta de la calle de la Mar, 1810, pp. 1-2.

6. Aymes, op. cit. pp. 96 y ss. 
muy bien en el carácter popular de la propaganda. Incluían menciones a los orígenes oscuros de la familia, a la codicia de sus parientes e, incluso, a su aspecto físico, no excesivamente majestuoso; este punto serviría también para compararlo con don Quijote. Eso mismo hacía uno de los textos objeto de este trabajo, escrito por Francisco Meseguer ${ }^{7}$ en los primeros momentos de la Guerra del Francés. Fingiendo un sueño, había visto a «un hombre de poca estatura, armado como suelen los coraceros franceses, y en su espaldar un cartelón que decía: este es el caballero de la mala figura» con evidente intención despectiva. Frente a él estaba un

manchego al parecer, según indicaba el vestido que traía. Un asno rucio y un caballo flaco pacían libremente por allí cerca. Desde luego me ocurrió que esta escena tenía no poca semejanza con alguna de las que ofrece la historia de don Quijote. (p. 4)

aunque eran Napoleón y Sancho Panza. Del afán por desprestigiar al Emperador acentuando su figura — ésta sí triste - hay múltiples ejemplos en las caricaturas y hojas volantes impresas durante la guerra, a partir de $1808^{8}$. Desde esa misma fecha se lanzaba contra Napoleón una auténtica orgía de insultos; el mismo Catecismo Civil establecía desde un primer momento la maldad absoluta de Napoleón, dotado de dos naturalezas, «una diabólica y otra humana [...] Uno verdadero, pero trino en personas falsas. ¿Cuáles son? Napoleón, Murat y Godoy» ${ }^{9}$.

Entonces, dado el arsenal ideológico-literario a disposición de los patriotas, ¿por qué sacar a la palestra a don Quijote para alimentar el sentimiento antinapoleónico? Además, era un recurso que no todos compartían; por ejemplo, Antillón, quien echaba de menos la publicación de obras que pudieran iluminar el momento histórico, mientras lamentaba que

no presentan nuestras imprentas a la Europa más que composiciones miserables, donde la lengua castellana se mancha con dicterios groseros y expresiones bajas contra la persona y familia del tirano que trata de subyugarnos, y a quién con las bayonetas, con la razón y con el buen gobierno, no con tales y despreciables recursos, debemos hacer la guerra ${ }^{10}$.

7. Meseguer, Francisco, El Don Quijote de ahora con Sancho Panza el de antaño, Córdoba, s.n., 1809. El Don Quijote de ahora de Meseguer se reproduce en facsimilar por González Castaño, Juan, y Martín-Consuegra Blaya, Ginés José, Impresos de patriotas: antología de la publicística en el Reino de Murcia durante la Guerra de la Independencia (1808-1814), Murcia, Universidad de Murcia, 2006.

8. Por ejemplo, en el impreso Napoleón y sus consejeros van a ver al can Cerbero, en la exposición «Miradas sobre la Guerra de la Independencia», Biblioteca Nacional, BNM invent 43519. El consejero del Emperador es un diablo que lo lleva a hombros, está claro que al infierno. En otro impreso de la misma exposición, Los parientes del Corso en la Corte del Emperador de las Galias, se muestra a la familia de Napoleón bajo el aspecto de un hato de desharrapados. BNM, invent. 43521.

9. Catecismo civil, s.l., s.n., 1808, publicado en Guerra de la Independencia. Proclamas bandos y combatientes, Sabino Delgado (ed.), Editora Nacional, Madrid, 1979, p. 295; García Cárcel, Ricardo, El sueño de la nación indomable, Madrid, Temas de Hoy, 2007.

10. Antillón, Isidoro, Cuatro verdades útiles a la nación extractadas de algunos escritos españoles, Palma, Domingo, 1810, p. 5. 
Los textos en que esto ocurre son solamente una pequeña fracción de la producción propagandística de la Guerra de la Independencia, verdaderas curiosidades entre el gran número de escritos patrióticos de la época, tanto que han pasado inadvertidos para muchos de los historiadores que han analizado la literatura política del período ${ }^{11}$. ¿Por qué acudir a don Quijote? Para intentar hallar una explicación se puede recurrir a relaciones intertextuales, escuchando el diálogo escrito entre autores de la época. El patriota anónimo que repasaba lo que sobraba y faltaba en España en tan trágicos trances se quejaba de que no había

vestuario para las tropas que ofrecen sus pechos a la defensa de nuestra religión, nuestra independencia y nuestras propiedades,

\section{a la vez que demasiado se veía}

lujo y profusión en nuestros petimetres y damiselas que, dominados de la más abominable indiferencia, lo mismo les importan los sucesos prósperos, que los adversos de nuestras armas, y son incapaces de dolerse de las fatigas y necesidades del infeliz soldado ${ }^{12}$.

Aparentemente había acertado en su diagnóstico y, entonces, ante esa situación, contestaban otras voces, nadie había mejor que don Quijote para encarnar la abnegación, el sentido del sacrificio y el esfuerzo precisos para

11. A propósito de la Guerra de la Independencia, el antinapoleonismo y la propaganda política, véanse, entre otras, las siguientes obras, amén de las arriba mencionadas: Dérozier, Albert, Escritores políticos españoles (1789-1854), Madrid, Turner, 1975; Marco, Joaquín, Literatura popular en España en los siglos XVIII y XIX. Una aproximación a los pliegos de cordel, Madrid, 1977; Battesti Pelegrin, Jeanne, «Nommer l'innomable: à propos de la rhétorique des proclamations populaires de la Guerre d'Indépendance», en Les Espagnols et Napoléon, Aix-en-Provence, Université de Provence, 1984, pp. 205-228; Aymes, Jean-René, España y la Revolución Francesa, Barcelona, Crítica, 1989; Teatro politico spagnolo del primo Ottocento, Ermanno Caldera (ed.), Roma, Bulzoni, 1991; Petiteau, Nicole, Napoléon de la mythologie à l'histoire, Paris, Seuil, 1999; La Guerra de la Independencia. Estudios, Armillas Vicente, Juan Antonio (coord.), 2 vols., Zaragoza, Institución Fernando el Católico, 2001; Se hicieron literatos, op. cit., pp. 63-82; Conflicto y sociedad civil en la España napoleónica. Actas de las quintas jornadas sobre la batalla de Bailén y la España contemporánea, Jaén, Universidad de Jaén, 2004; La Guerra de la Independencia en la cultura española, op. cit.; El comienzo de la Guerra de la Independencia. Congreso internacional del bicentenario, Emilio de Diego García (dir.) y José Luis Martínez Sanz (coord.), Madrid, Actas, 2008. En ninguno de tales títulos hay ejemplos de la «quijotización» de la propaganda, como tampoco en los repertorios de caricaturas políticas como los de Dérozier, Claudette, La Guerre d'Indépendance espagnole à travers l'estampe (1808-1814), 3 vols., Toulouse, Université de Toulouse, 1976; ídem, «La caricature anti-napoléonienne espagnole», en Les Espagnols et Napoléon, Aix-en-Provence, Université de Provence, 1984, pp. 197-204. Sólo recientemente Romero Peña y Álvarez Barrientos han señalado algunos de los títulos aquí analizados. Al redactar este artículo había sido imposible consultar la ponencia de López Navia, Santiago Alfonso, «El Don Quijote de ahora con Sancho Panza el de antaño, de Francisco Meseguer (1809) y la huella del nacionalismo españolista en las recreaciones narrativas del Quijote», en Tus obras los rincones de la tierra descubren. VI Congreso internacional de la Asociación de Cervantistas (13-16 de diciembre de 2006), Alexia Dotra Bravo et al. (eds.), Alcalá de Henares, Centro de Estudios Cervantinos, 2008.

12. Faltas y sobras de la España, s. n., s. 1., s. a., p. 2. Probablemente inspirada en Francisco Santos, El no importa de España, tratado sobre la decadencia del país publicado en 1667. 
atender a las necesidades del momento o al menos para servir de ejemplo. Por cierto que ese mismo «no importa de los españoles», al parecer sacado de la Gaceta del 29 de diciembre de 1811, en la que se describía «el carácter de una nación valiente, es cierto, y generosa, pero llena de aquella vana confianza, que indispensablemente produce las más funestas consecuencias» parece un retrato acertado del caballero andante. Los afrancesados lamentaban que «Esta expresión, hija de la imprudencia, ha sido la divisa de los que sin calcular los intereses de la nación se han empeñado en seguir un sistema propio sólo para arruinarla» y reían de los patriotas que decían «no importa» tras cada derrota de los españoles. Pero un escritor que más adelante se analizará, Clemente Carnicero, la usaría para recriminar a los franceses que el pueblo del «no importa» los estaba derrotando. En el campo de la pintura cabe reseñar también que Zacarías González Velázquez fue autor de «una colección de cuadros, sobre la Historia de don Quijote, cuya colección consta de 14 cuadros originales. Esta exaltación pictórica del paradigma de caballero español que se enfrenta a los gigantes acompañaría al retrato ecuestre de Wellington por Francisco de Goya en las salas de San Fernando a comienzos de septiembre de 1812, en un Madrid temporalmente liberado por los ingleses» ${ }^{13}$.

Recurrir al Caballero de la Triste Figura con este propósito, sin embargo, significaba interpretarlo de una manera que no era desde luego compartida por todos los autores; porque para otros, por el contrario, el manchego no podía representar más que al invasor, y para denigrarlo. Esto es así porque en relación con la tradición literaria del siglo XVIII, el uso de don Quijote como elemento de propaganda política representaba una novedad, pero sus premisas teóricas se remontaban a aquel momento, a causa de la indeterminación interpretativa de la obra cervantina. De hecho, la condición necesaria para que tal manipulación de don Quijote y el universo de su novela pudiera llevarse a cabo fue el que llegara al siglo XIX «sin interpretar», como ha dicho Rodríguez Cepeda ${ }^{14}$, lo que era fruto de la falta de definición crítica del personaje cervantino durante todo el siglo XVIII o, más bien, de la multiplicidad de presentaciones distintas del mismo, y ninguna satisfactoria. Probablemente esta enorme indefinición valorativa era el legado que la carencia de precisión crítica dieciochesca había dejado en herencia a los elaboradores de los panfletos anti-napoleónicos de la Guerra de la Independencia y, desde luego, éstos la aprovecharon cada uno a su favor. Las dificultades que los literatos dieciochescos encontraban a la hora de enjuiciar la novela cervantina se ponen de manifiesto en el hecho de que para algunos era un texto con valor positivo ya que tenía el mérito de haber acabado con las novelas de caballería mientras que para otros era edificante porque en el Siglo de las Luces la sátira moralizaba. Así es como para los ilustrados la figura de don Quijote podía

13. De la Mano, José Manuel, «Goya Intruso. Arte y política en el reinado de José I (1808-1813)», en Goya en tiempos de guerra. Catálogo de la exposición, Madrid, Museo del Prado, 2008.

14. Rodríguez Cepeda, Enrique, «Sobre el Quijote en la novela del siglo XVIII español», Ínsula, 546 (1992), pp. 19-20 
ser uno de los resortes de su política cultural en pro del llamado buen gusto, mientras que para otros escritores coetáneos el quijotismo se tomaba como valor negativo y se interpretaba como la crítica del afán de enriquecimiento, de las pretensiones de nobleza o - y aquí hace al caso- de las actitudes personales y sociales «extravagantes». Luego la característica más importante de los textos quijotiles del XVIII es «la falta de uniformidad ideológica», porque a don Quijote recurrían autores retrógrados o progresistas para hacerlo objeto o portavoz de sus opiniones; común en cambio era casi siempre el «carácter crítico-satírico» de lo que se escribía inspirándose en el legado cervantino ${ }^{15}$. Tomada desde el punto de vista del siglo ilustrado, la figura de don Quijote participaba de una doble interpretación, siendo por una parte la imagen que la tradición había formado ya desde el Seiscientos: bufa, festiva y ridícula, pero, por otra parte, en ella se injertaba la lectura moralista, propia de la época, que no anulaba la visión más antigua sino que se solapaba a ella y en cierto sentido la desarrollaba alejándose cada vez más del modelo original.

Éste es el punto de partida del presente trabajo, que intentará poner en evidencia los dos hechos fundamentales del uso político de don Quijote desde el punto de vista exclusivo de la polémica histórica, no de la literatura: la variedad de interpretaciones del personaje y la lectura selectiva de la novela, que se hacía para extraer de ella los episodios más adecuados para los fines propagandísticos que se buscaban. Este segundo aspecto implica también que para conseguir esos mismos fines los autores de los textos de propaganda debían presuponer entre el público un conocimiento general de las aventuras del caballero manchego o, de lo contrario, el mensaje de sus opúsculos no habría tenido eficacia; y de admitir estas dos premisas, habría que concluir que la sociedad de principios del siglo XIX conocía — en mayor o menor gradolos avatares de Sancho Panza y don Quijote, pero no tenía un criterio claro acerca del carácter del caballero y su escudero. Por lo que pueda valer, como testimonio interesado, y para poner en duda el conocimiento real de la novela cervantina, cabe recordar también las palabras de un soldado napoleónico a su paso por La Mancha: «Pues bien, ¿puede creerse que no haya cuatro vecinos en El Toboso que conozcan a Cervantes y que casi todos preguntasen quién era la tal Dulcinea de la cual con tanto regocijo se hablaba? ${ }^{16}$.

He aquí, pues, un aspecto de la aproximación al problema: la relación, en la cultura y la mentalidad populares, entre la novela cervantina y sus personajes.

15. Aguilar Piñal, Francisco, «Anverso y reverso del quijotismo en el siglo XVIII español», Anales de literatura española, I (1982), p. 117; Barreo Pérez, Óscar, «Los imitadores y continuadores del Quijote en la novela española del siglo XVIII», Anales Cervantinos, XXIV (1986), pp. 103-121; Rodríguez Cepeda, Enrique, «Los Quijotes del siglo XVIII: 2. La imprenta de Juan Jolis», Hispania, 71, 4 (1988), pp. 752-779; Luis M. Enciso Recio (ed.), Actas del Congreso Internacional El Dos de Mayo y sus Precedentes, Madrid, 1992; Álvarez Barrientos, Joaquín, La novela del siglo XVIII, Madrid, 1991; Rivas Hernández, Ascensión, Lecturas del Quijote (Siglos XVII-XIX), Salamanca, 1998; también, desde el punto de vista iconográfico, Lucía Megías, José Manuel, Leer el Quijote en imágenes: hacia una teoría de los modelos iconográficos, Madrid, Calambur, 2006.

16. Fée, Antoine Laurent Apollinaire, Recuerdos de la guerra de España, llamada de la Independencia. 1809-1813, Jesús Navarro Villalba (ed.), Madrid, Ministerio de Defensa, 2007. 
Los vecinos del Toboso no conocían a Cervantes - es decir, la novela - pero daban por hecho la existencia de uno de sus personajes: Dulcinea. Igualmente es posible que de un conocimiento muy superficial del libro se supiera que narraba los hechos de un lunático que emprendía locas aventuras y bajo esta reducción se justificaba la mención a Napoleón, como en el Sueño del Tío José, donde se lo comparaba con don Quijote para hacerlo ridículo siguiendo una interpretación tan superficial como manida:

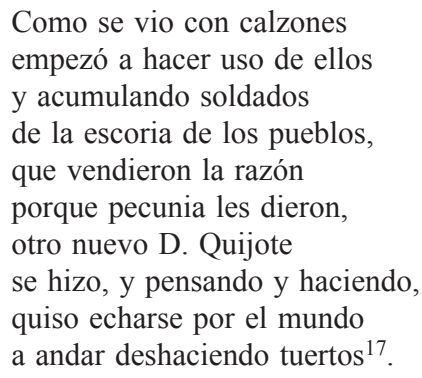

Entre el público popular también debía ser proverbial el gusto de Sancho por los refranes y así en una hoja suelta sin fechar pero prácticamente contemporánea, la Carta que un español escribe a Murat, se aplicaba el mismo recurso para usar la novela como arma de propaganda. Construida sobre una serie de refranes ensartados uno tras otro para componer una arenga patriótica, la firmaba «El Gobernador Sancho Panza, que fue de la Ínsula Barataria», para indicar que el reinado de José I sería tan efímero como el gobierno del escudero $^{18}$, con la diferencia de que, a pesar de haber sido un gobernador ilusorio, éste había dado pruebas de rectitud. Pero de un recurso genérico a la novela se pasaba inmediatamente a la personalización cuando Sancho llegaba al punto de recordar su experiencia, naturalmente para contraponerla a la gestión del poder por parte de Napoleón, y concluía con una reivindicación de su historia:

Yo fui gobernador de una ínsula que, según hago memoria, se llama la Barataria, que viene a caer enmedio enmedio y en el mismo riñón de España: fui allá con el beneplácito de su dueño y con la bendición de Dios y de la de mi amo; mis insulanos me recibieron en palmas, y yo goberné con muchísima cristiandad y desinterés, que si V. M. leyera la historia allí lo vería: pues con todo eso, lo que yo adelanté en cuatro o cinco días que me duró el Gobierno, fue trabajar mucho, comer poco, dormir menos, y una noche que los enemigos asaltaron la ínsula, me entortugaron mis vasallos entre dos gamellones, y me convirtieron en galápago, y pasé tantas bascas y fatigas y tanto sudor y congojas, que pues no di entonces a Dios mi ánima, no hay más sino que no tenía mis días cumplidos, de manera que yo tomé a buen partido irme bien a bien y callandico, y dejar la ínsula,

17. El sueño del Tío José, que quiso ser primero, y quedó cola, Madrid, Repullés, 1808, p. 8.

18. Carta que un español escribe a Murat sobre sus aventuras en España, reimpreso en la Casa de la Misericordia de Cádiz, s.a., pp. 25-26. 
dando al diablo la negra hora en que entré en codicia de salir de mi paso, y remontarme a las nubes, sin conocer que por su mal le nacieron las alas a la hormiga, porque cada uno es para lo que es, y al que Dios lo crió para cornado no será escudo, y el ollero que haga sus ollas, porque la codicia rompe el saco, y si no ahí está la rana de Guisopete, que se empeñó en ser tan grande como los bueyes, y tan hinchada se puso, que dio un esclavigio, y se quedó espatarrada.

Como habrá podido verse, y se observará más adelante, se suponía que los lectores conocían la historia del caballero - la novela - pues, de lo contrario, la sátira no habría surtido efecto. Sería indudablemente un conocimiento superficial, anclado en algunos de los episodios o hechos más famosos, que se habrían convertido en patrimonio cultural común. Estas piezas de literatura política de ocasión ofrecen así una valiosa indicación indirecta de la idea de don Quijote y también de su novela en la mentalidad popular, hasta el punto de que permiten suponer que muchos de los avatares novelescos del Hidalgo de La Mancha habían adquirido valor proverbial en España a principios del XIX. Al menos esto es cuanto se desprende de Napoleón o el verdadero D. Quijote, escrito para comentar y atacar los edictos de Napoleón de diciembre de 1808. Para alcanzar su objetivo Clemente Carnicero ${ }^{19}$ recurrió en varias ocasiones a auténticas descontextualizaciones de varios pasajes de la novela transponiéndolos a situaciones del momento, elevándolos a categorías generales. Por ejemplo, comentando el decreto de 12 de noviembre de 1808, de condena a muerte de varios patriotas, exclamaba (I, p. 8):

¡Válgame Dios, y qué lástima! Pobrecitos de estos señores: me temo, me temo, que si las manos del señor emperador son tan largas como su ira, los ha de coger aunque se metan en la cueva de Montesinos, y se escondan más que lagartijas, pues de allí, como nuestro don Quijote, los sacará, mal que les pese.

El Emperador había amenazado a los patriotas españoles y para él los resistentes madrileños no eran sino «follones y malandrines» (II, p. 24).

Clemente Carnicero también recurría a la novela cervantina para trazar paralelismos, obviamente desfavorables al segundo, entre don Quijote y Bonaparte. En su texto se tomaban como objeto de crítica los decretos del

19. Clemente Carnicero, José, Napoleón o el verdadero D. Quijote de la Europa o sean Comentarios crítico-político-burlescos a varios decretos de Napoleón y su hermano José, distribuidos en dos partes y cincuenta capitulos, y escritos por un español amante de su patria y rey desde primero de febrero de 1808 hasta fines del mismo año, Madrid, Ibarra, 1813; otra edición en Madrid, Ibarra, 1825. La autoría del Napoleón o verdadero D. Quijote resulta del prólogo de otra obra de Clemente Carnicero, Historia razonada de los principales sucesos de la gloriosa revolución de España, Madrid, Burgos, 1814, en la que afirma: «Si omito otros [sucesos] es porque ya di razón de ellos en la obra del Napoleón o don Quijote de la Europa». Clemente era oficial del Archivo de la Secretaría de Gracia y Justicia de Indias y también escribió, después de la guerra, una impugnación de los Anales de Llorente: La Inquisición justamente restablecida, Madrid, Manuel de Burgos, 1816. Era pues claramente un conservador antiilustrado. 
Emperador de diciembre de 1808 y se los comparaba, de manera burlesca, con hechos de la novela: ya de por sí este recurso rebajaba la tarea legislativa napoleónica a nivel de simple cuento, pero además Clemente Carnicero reducía las tareas del gobernante a quijotadas:

\footnotetext{
Españoles míos: yo quisiera que estos comentarios fueran tan buenos que unas veces os hicieran reír de los proyectos y disparates de Napoleón como las locuras de don Quijote.
}

decía en el prólogo. Aquí sí que el Ingenioso Hidalgo no es más que un pobre mentecato, y Napoleón resulta ser el reflejo de esa imagen deformada. A propósito de la abdicación de Bayona, ni Napoleón ni José «pudieron exigir con derecho juramento ni vasallaje alguno, ni menos conferirles empleos sino de la manera y al modo que lo hacía don Quijote con su buen escudero» (I, p. 13), esto es, ilusoriamente. Se reía de la fundación del Tribunal de Reposición porque el autor pensaba que para Napoleón «Tal tribunal es como el bálsamo de Fierabrás, que curaba todos los males» (I, p. 67). Mofándose de los decretos de reducción de los regulares se preguntaba si a Napoleón «¿No se le podrá aplicar aquello que en cierta ocasión dijo don Quijote a Sancho: echa, ensarta, enhila, promete y dispón, que nadie te va a la mano?» (II, p. 135). El texto encontraba más paralelismos entre el manchego y el corso, no ya apoyándose en frases o dichos, sino incluso en episodios dignos de unas vidas paralelas: durante su visita a sus nuevos súbditos, el rey José I había pasado por el pueblo de Miguelturra, donde le dieron una bienvenida no precisamente calurosa. Pero la realidad terminaba siendo una repetición de la novela:

\footnotetext{
Cupo la suerte a la famosa de Miguel Turra, que impelida de la misma fuerza, envió sus diputados, que hicieron su cumplido al nuevo rey [...]. Bien se acordarán los que hubiesen leído las aventuras de don Quijote, que entre los personajes, que molestaron a Sancho en su gobierno, fue un socarrón de Miguel Turra. (II, pp. 78-79)
}

pues uno de los diputados de la villa acusó a los soldados imperiales de haber cometido todo tipo de violencias y desmanes: «entonces el señor José ique tal oyó! quedó pasmado y no tuvo otro arbitrio que encoger los hombros y hacer Tirte afuera» (pp. 80-81).

Una referencia del mismo tipo hay a propósito de la imposición de la Contribución Única, que en el texto toma valor de parangón sarcástico con una aventura de don Quijote,

de las que menos honor le hicieron (pues trataban de prenderle por malhechor los cuadrilleros) se puso tan furioso y fuera de sí, que para hacerle desistir de tan ruin e inesperada empresa prorrumpió en los siguientes términos: ¿quién fue el ignorante que firmó mandamiento de prisión contra un tal caballero como yo? ¿Quién el que ignora que los caballeros andantes son exentos de todo judicial fuero, y que su ley es su espada, sus fueros sus 
bríos, y sus pragmáticas su voluntad? ¿Y qué caballero andante pagó pecho, alcabala, chapín de la reina, moneda forera, portazgo ni barca? Pues ahora, españoles míos, volviendo la medalla ved en su reverso a nuestro gran Napoleón que con su espada y mano extendida nos dice en estos decretos ¿Qué emperador andante como yo no abolió el derecho feudal? ¿Quién no quitó toda carga personal? (II, pp. 184-185)

Es preciso notar que este tipo de referencias directas a acontecimientos que ocurren en la novela es muy distinto de los comentarios genéricos a la figura y al carácter, reales o supuestos, de don Quijote: Napoleón limitó las encomiendas a una por persona, y el texto comenta que «en esto también quiso imitar a don Quijote, que aún no estaba armado caballero, y ya se creía coronado en el mayor reino del mundo» (I, p. 6). En otro ejercicio más elaborado de búsqueda de puntos en común, Napoleón o el verdadero D. Quijote ridiculizaba a los soldados franceses que «en su traje, bella apostura y brío mostraban todos a tiro de escopeta ser unos grandes religiosos de la orden militar, y de caballería la más estrecha» (II, p. 95) pues

\begin{abstract}
una de las cosas de que más se preciaron los caballeros andantes, y singularmente nuestro don Quijote, fue de que la caballería andante era también religión; pero tan austera y trabajosa que excedía a la de los cartujos. Instruido sin duda en la misma escuela nuestro andante Napoleón quiere no sólo imitarle, sino excederle en tercio y quinto.
\end{abstract}

Habría que preguntarse cómo lo consiguió, y el autor lo explicaba. El hecho era que, una vez entrados en Madrid, los soldados imperiales tan religiosos mandaron desalojar a los frailes para ocupar sus conventos (II, pp. 92-96), se entiende que para acuartelarse, superando así al hidalgo al hacer de sus soldados monjes. También es mera referencia literaria «la Quijotesca fanfarronada de los franceses de haber arrollado con sola su vista el ejército de los valientes extremeños, y se les vindica de la calumnia y falsedad con que publicaron su total derrota» (III, p. 131).

De la novela cervantina el Sancho Panza de Meseguer recordaba tres episodios para construir la figura heroica de su amado señor. Dado el carácter propagandístico del libelo, habrá que admitir que esos hechos de Don Quiote debían pertenecer a la cultura popular o de lo contrario el mensaje de Meseguer habría perdido parte de su eficacia. En el sueño de Meseguer se recuerdan por lo tanto el episodio de la batalla de los rebaños (Quijote I, XVIII), el de la liberación de los galeotes (Quijote I, XXII), y el de la Princesa Micomicona (Quijote I, XXIX). La finalidad del primero era alabar el valor del caballero:

Una vez venía por aquellos campos un ejército tan grande que el polvo allegaba al cielo, y el balamio de las gentes se hundía el mundo, y delante un Rey Pagano que se llamaba Fanfarrón o Faraón, o una cosa así, con el brazo remangado, y las puertas de Sansón acuestas, y un cuero de serpiente, y un gato maullando con tantas uñas y de zaga, quién sabe lo que allí venía de Moros y de Judíos, y de todas las naciones, negros y blancos, y Garamantas, 
y... vamos... de todas setas, hasta un Francés, para que hubiera de todas malas semillas; pero mi amo enderezó con todos ellos, y si no es por un demonio de nigromante que a todos los volvió carneros, ésta es la bendita hora que no ha dejado con vida ni uno siquiera de toda aquella canalla; y esto no hay en toda la Francia un hombre que tenga valor para hacello, y yo lo digo y apuesto el rucio que ni V. M. tampoco. (pp. 10-11)

El otro recurso propagandístico consistía en tomar directamente al personaje central de la novela, o a su escudero, para encararlo con el invasor; y los textos que recurren a este medio polémico son significativos por los motivos que ahora se verán. Son los ya citados El don Quijote de ahora de Meseguer, Napoleón o el verdadero D. Quijote de la Europa de Clemente Carnicero y el Diálogo entre D. Quijote de la Mancha y Sancho Panza su escudero, este último de autor anónimo ${ }^{20}$. Las tres obras usaban los personajes de la novela, pero en ellas se aprecia que los autores los valoraban de manera muy diferente.

El don quijote de ahora... y Napoleón o el verdadero D. Quijote... encarnaban al hidalgo en la persona del enemigo Napoleón; solamente el Diálogo... presentaba a los personajes cervantinos en sus colores más o menos naturales, ejerciendo caballero y escudero de buenos patriotas en pláticas de rancia filosofía política. En el texto de Meseguer el mismo escudero encontraba la manera de hacer unas deliciosas digresiones acerca de la figura del caballero desmitificando en buena parte los elogios que le dedicaba, demostrando al final un sentido común y un realismo muy necesarios para el fin al que se aplicaba. No hay que tomar sus palabras como una recapitulación analítica de la novela cervantina sino como anticipación de la aventura napoleónica, destinada de antemano al fracaso:

Sí señor, ¿y qué le sucedió a mi amo por querer sacar las cosas tan de su quicio? Que salió bien de una aventura de poca monta, y se metió en otra de más aquél, y se fue llenando de ventolera y de atrevimiento, al final se quiso subir tan a mayores, que salimos no pocas veces con las manos en la cabeza; porque el que mucho abarca poco aprieta, y nadie ha de tomar más bocado del que puede revolver, ni estirar el pie más de lo que sufre la manta. (p. 23)

Es lo que hacía Meseguer en su libelo, arrancando de la novela cervantina para comparar las hazañas del auténtico caballero con los hechos del nuevo don Quijote, Napoleón Bonaparte. «El que reflexione que yo soñaba, disimulará el grandísimo anacronismo que supone mi narración» decía el autor en la Introducción. Sin embargo Meseguer intentaba hacer un análisis más articulado de la política y del hombre, superando la popular representación chocarrera $\mathrm{y}$, en el fondo, de poco alcance del enemigo. 
El corso encarnaba la figura grotesca que la Ilustración había visto en don Quijote, pero, para que la comparación tuviera sentido, Meseguer había de aceptar que el verdadero caballero andante fuera portador de valores positivos. El discurso se desarrolla recurriendo a la construcción de un don Quijote «auténtico» mediada por los ojos de Sancho Panza, quien se convierte de hecho en el exegeta del personaje novelesco y de sus aventuras, gracias a las constantes referencias a sus recuerdos y a su reelaboración personal de lo ocurrido en la novela. Haciendo esto, Meseguer sin proponérselo emprendía un estudio del personaje cervantino que es, sin duda alguna, lo más interesante de su texto, ya que Sancho/Meseguer establecían un canon interpretativo literariopsicológico del héroe manchego. Además, Meseguer es importante porque los hechos recordados en el opúsculo indican a la vez los episodios novelescos que probablemente debían formar parte del patrimonio cultural popular. La gran ambivalencia de la obra de Meseguer consiste en el hecho de que el Don Quijote de ahora no era, evidentemente, el personaje cervantino sino Napoleón, y el auténtico hidalgo de La Mancha, el supuesto personaje real era, a su vez, un mero reflejo en la memoria del escudero: el único personaje «verdadero» resultaba de esa manera, paradójicamente, Sancho Panza. Y un típico recurso cervantino para certificar la autenticidad del escudero era, como se puede comprobar en muchos textos semejantes, el uso de los refranes con que Sancho sazonaba sus razonamientos. El texto abunda también en el fácil retruécano entuerto/tuerto, deshacer entuertos/hacer tuertos, entendido en el sentido de hacer perder un ojo a alguien y, en sentido amplio, de causar estragos, heridas y muertes como eran los efectos de la política de Bonaparte.

El diálogo de Meseguer es importante desde el punto de vista histórico dado que representa una intervención de primera magnitud en la situación política del momento, ya que brindaba a los lectores razones políticas y éticas para luchar contra los franceses desde los primeros momentos de la contienda ${ }^{21}$.

Sancho empezaba ufano anunciando la formación de la Junta Central Suprema, nacida en septiembre de 1808 para organizar la resistencia a las armas francesas pero ahora Napoleón se encargaba de enfriar sus ardores patrióticos:

SANCHO - Ha de salir a campana tañida la santa hermandad de todos los Españoles, que ya se zunzunea que se ha juntado en los Aranjueces o en los Madriles, y tanto se le da a ella V. M. y de todos sus hechos y caballerías, como del Rey que rabió por gachas.

BONAPARTE - Hablas sin duda por una Junta que llaman Central, de cuyos aciertos se prometen los Españoles grandes ventajas; pero a pesar de esa

21. «En el diálogo entre Sancho Panza y Bonaparte, publicado por Francisco Meseguer, primero en Córdoba (España) y luego en México (1809), con el título de El don Quijote de ahora con Sancho Panza, el de antaño, se da un ejemplo del uso político de la novela, relativamente frecuente en los años de la Guerra de la Independencia y, después, de cómo en México se utilizó para rechazar la política francesa». Álvarez Barrientos, Joaquín, El Quijote en Europa y América en los siglos XVIII y $X I X$ [en línea], disponible en 〈www.seacex.com/documentos/05_tapices_qute_europa〉. 
que tú llamas santa hermandad de todos los Españoles, reinará sobre ellos mi hermano José, porque yo lo he decretado, y mi poder es irresistible. (pp. 24-25)

Mas casi, casi, parecería que el Sancho de Meseguer se hubiera embarcado en un ejercicio de análisis moral más allá del mero alcance propagandístico del texto dado que no se ceñía a echar en cara a Napoleón las virtudes de don Quijote, sino que también introducía un matiz de desengaño en el sentido de la acción política. Se trata de una sombra apenas esbozada, tal vez sencillamente el eco de uno de los episodios más conocidos de la novela, pero es lícito preguntarse hasta qué punto Meseguer ha revelado su pensamiento más íntimo - o ha sido traicionado por su subconsciente-. El hecho es que las consideraciones políticas y los discursos del escudero están teñidos de un escepticismo pesimista seguramente involuntario pero extremadamente cervantino. Sancho recordaba que para su amo «el hacer bien a villanos es como echar agua en el mar, y yo digo que el que en mala tierra siembra cogerá abrojos» (p. 16). Ahora bien, ¿quiénes podían ser esos villanos en la guerra contra el francés? La expresión no se puede entender como aviso a Napoleón, porque al patriota no debía importar que al final los proyectos del Emperador fracasaran; pero tampoco a los gobernantes legítimos españoles, dado que precisamente el pueblo - los villanos - era los actores de la guerra. Sancho seguía desarrollando su opinión afirmando que «mi señor D. Quijote, que en paz descanse, tenía algunas cosas de hombre mayor» y así terminaba calificando la liberación de los galeotes, que «un día se le puso en la cabeza»:

Había de poner en libertad a ciertos galeotes, que por sus malas obras iban a remar a las galeras de España; no le bastaron a su merced ni ruegos, ni nada de cuanto yo hice para apartarlo de aquel mal pensamiento, porque tenía esa faltica, que como se empeñara en una cosa, no le harían cejar si le predicaran Frailes descalzos: él, ya se ve, como era tan valiente, en dos idas y venidas alanceó y ahuyentó a los guardas y soldados que escoltaban a aquellos picarones, y yo ayudé a quitar las cadenas, y quedaron los perillanes sueltos y libres como el corzo en el monte; y isabe V. M. el galardón que tuvimos por tan buena obra? Que mi amo les mandó que fueran a presentarse a su señora Doña Dulcinea, y ellos dijeron que, menos eso, cuanto les mandara; y mi amo se empeñó en que habían de ser pares y ellos que nones, y empezaron a remolinear y hacerse del ojo, y se hicieron azaga, y descargaron sobre nosotros tal tempestad de palos y tal granizada de piedra, que en menos que lo digo derribaron a mi señor de su buen rocinante, y le rompieron en la cabeza el yelmo de Malandrino, todo de oro, que era la mejor vacía que había tenido ningún barbero del mundo; y por último, después de muchos palos y mojicones y coces y pedradas, nos dejaron revoleados por aquel campo, molidos como cibera, y se fueron a bribonear por esos mundos de Dios. (pp. 17-18)

Pretender expulsar al invasor queda al mismo nivel que la antojadiza liberación de los galeotes, justamente sentenciados. Entonces, ¿luchar por la liber- 
tad no sería más que la alucinación de un viejo senil? Meseguer ciertamente no estaba sugiriendo - al menos conscientemente - tal cosa. En cambio en su texto don Quijote era completamente positivo, representaba la verdadera grandeza ética y en él habían de mirarse quienes fueran buenos españoles.

En el sueño de Meseguer, Napoleón quería saber por qué Sancho no lo consideraba tan buen caballero como a su amo; porque uno deshacía entuertos, respondía el escudero, y «V. M. todo lo va torciendo por donde pasa». Según el ideario patriótico el Emperador era

caballero andante contrahecho [porque] los soldados de V. M. han desbaratado y deshecho un sin fin de doncellas, y han forzado castas y viudas, y dejan llorando a los que estaban contentos, y desamparados a los que tenían arrimo, y huérfanos a los que tenían padre, y sin hacienda a los pupilos y a sus tutores, y pelean contra los buenos como el Rey D. Fernando y todos los fieles Españoles, y defienden y amparan los malos como Godoys y todos los traidores que lo han seguido. (p. 16)

Napoleón entonces preguntaba cómo era que don Quijote a pesar de su bondad no había llegado a ser nada, pero Sancho también tenía réplica para eso:

Vaya, yo no sé cómo hay gentes que digan que V. M. es tanto y cuanto de sabihondo, cuando no sabe tan siquiera la historia de D. Quijote; mi amo tuvo en la mano el ser Rey de un reino siete u ocho veces más grande que medio mundo, porque de más allá de las tierras de los negros vino la doncella más hermosa que mis ojos han visto a buscar a mi señor por la fama de su valor y de sus virtudes. (p. 19)

Sancho iba formulando, una tras otra, objeciones a la política que Napoleón estaba siguiendo y, siempre que le era posible, lanzaba flechazos críticos al Emperador: «digo que yo sería tan incauto y tan inocente como el Rey D. Fernando si me fiase de semejante palabra [de Napoleón]; y si aquel buen Señor y sus Consejeros tomasen el mío, otro gallo les cantaría a ellos y a todos los españoles» (pp. 7-8). El discurso patriótico se desarrolla en dos líneas argumentales, la del ataque directo a Napoleón, a su familia, a su corte:

V. M. es caballero andante contrahecho, porque, como no le viene de casta, hace todas las cosas al revés de cómo las hacía mi amo y las hacen todos los caballeros buenos y legítimos; porque lo primero que hacía mi amo era enderezar todos los tuertos que iba encontrando, y V. M. todo lo va torciendo por donde pasa, y aún no ha enderezado a ninguno que sepa yo, y si no hablen cartas y callen barbas, que lo que está a la vista no es menester candil; y ahí está el hermano de V. M. el señor D. José, que tuerto era, y tuerto es, y tuerto será mientras Dios lo tenga en el mundo; y más valía que todo ese empeño que ha tomado V. M. en hacerlo Rey de España, que será cuando la rana tenga pelo, lo hubiera tomado en enderezarlo y remendarle aquel ojo de demonio que tan mal le pega. (pp. 13-14) 
Y la otra sobre todo, que es la que da sentido al texto, la de comparar los hechos del Caballero de la Triste Figura con los del Gran Corso. Sancho entonces no perdonaba las acusaciones, sacando a la luz la falta de escrúpulos morales del Emperador. La ocasión de que se vale Meseguer para conseguir la mayor fuerza es el cervantino episodio de la princesa Micomicona, y el modo, la contraposición sanchopancesca de la actuación de cada uno de sus dos amos, el original y el soñado:

$¡ \mathrm{O}$ ! Yo lo creo, porque quien hace un cesto hará ciento; pero ráigasela del casco V. M. que lo que a mi amo le sobraba era talento, y lo que le faltaba era serenidad y descaro para hacer una trastada a vista de todo el mundo, porque yo soy un pobre porro, que no sé leer, y conozco que si mi amo, cuando estaba con aquella señora en la fragura de Sierra Morena, sin más amparo que Dios del cielo, le hubiera enristrado el lanzón y le hubiera hecho firmar una renuncia de todos sus derechos y estados a su favor, y luego se la hubiera dejado amarrada a un pino a que se la comieran los lobos, ya no tenía más que irse derechito a Micomicón, y reinar a pata tendida con la señora Doña Dulcinea: pero ¿qué hubieran dicho las gentes de semejante fechuría? Lo que dicen de lo que ha hecho V. M. con el Rey D. Fernando, que se puso en las de V. M. para que le favoreciese contra ese pícaro gigantón de Godoy, que le quería quitar el reino y la vida y la honra, y lo que el pobre mozo ha conseguido no se lo he de contar yo a quien lo sabe tan por entero, porque asesino como él no se ha hecho desde que hay mundo. (pp. 21-22)

El episodio de la princesa Micomicona es central para la construcción del discurso político antifrancés, porque representaba - a lo ojos de Sancho/ Meseguer - el ejemplo de la conducta de un auténtico caballero. Meseguer no se cansaba de repetir que don Quijote había actuado, en aquella ocasión, inspirado por el espíritu de la nobleza de ánimo de un auténtico caballero, para devolver un reino y no para usurparlo; Sancho lo contaba para marcar las diferencias entre el hidalgo y Bonaparte:

Mi amo tuvo en la mano el ser Rey de un reino siete u ocho veces más grande que medio mundo, porque de más allá de las tierras de los negros vino la doncella más hermosa que mis ojos han visto a buscar a mi señor por la fama de su valor y de sus virtudes, y aquella doncella era la Reina del gran reino de Micomicón, y si mi amo mataba a un gigantazo que tenía la vista fosca, y le había robado el reino, se casaba con ella, y lo hacía Rey coronado en un abrir y cerrar de ojos, y mi amo mató al gigante, que yo lo vi, y los nigromantes se lo volvieron pellejo de vino, y se enredó la aventura, y mi amo no fue Rey por lo que Dios quiso. (pp. 19-20)

No solamente porque Dios quiso; en juego estaban también los principios caballerescos, para desmentir el maquiavelismo demostrado por Napoleón en el diálogo. Cierto que

ha de saber V. M. que mi señor D. Quijote era un hidalgo tan honradote y un hombre tan cabal, que por no faltar a la fe y lealtad que tenía ofrecida 
a su señora Doña Dulcinea, no quiso ni aun pensar en casarse con toda una Reina de Micomicón, y eso que era doncella a carta cabal, lo mismo que si fuera hecha de cal y canto. (pp. 20-21)

Sancho no dejaba de marcar el contrapunto entre la grandeza de don Quijote y la mezquindad de Napoleón, rebatiendo una tras otra todas las explicaciones que éste le daba. También el manchego quería la gloria, pero siempre consciente de lo que costaba alcanzarla y teniendo siempre presente que había medios a los que no estaba dispuesto a recurrir:

\begin{abstract}
Ah bien; pues el que es temerario se pasa de valiente, y así era mi amo: pues por lo que hace a deseos de engrandecerse, iquién dirá los que tenía! Si no hablaba más que de ganar reinos, y de conquistar imperios y mares y ínsulas y todas esas cosas; pero aquel señor, como era tan cristiano, quería ganar las cosas como Dios manda, enderezando al que era tuerto, y consolando al que estaba afligido, y amparando al desamparado, y mirando por la honra de las doncellas, y por el qué dirán de las viudas, y por el abrigo de los huérfanos y pupilos, y peleando contra los malos y defendiendo a los buenos, y todo así; y luego había de correr la fama de sus virtudes por todo el mundo, y con eso y con su valor había de ser Rey de unas tierras de allá muy lejos que lo buscarían, y Emperador coronado, y detrás venía lo de la ínsula para mí; pero V. M. es otra casta de caballero andante, de los que mi amo llamaba contrahechos y follones y malandrines, bien que cada uno es como Dios lo hace, y el olmo no da peras. (pp. 10-12)
\end{abstract}

Este aspecto es puramente propagandístico y se puede enmarcar en la situación de la Guerra de la Independencia. Mas desde el punto de vista de la historia de la literatura el diálogo de Meseguer, por sus observaciones más allá de la política, adquiere un significado especial, por cómo analiza y reelabora el material cervantino. Hay unas pinceladas breves sobre la apariencia física del soñado caballero, que no se corresponden con la imagen del verdadero don Quijote: don Quijote/Napoleón de Meseguer era de hecho «un hombre de poca estatura» (p. 3) según lo había visto el autor en su sueño. En cambio en el mismo texto Sancho hablaba de su primer amo como de un hombre «alto como un pino, enjuto, membreño, airoso, galán y fuerte como una peña» (p. 29).

Pero donde la interpretación es más interesante es en el retrato psicológico. Decía Sancho:

Mi amo D. Quijote tenía su genio; pero vamos, era un señor que, mejorando lo presente, gustaba de oírme: y cuando íbamos por esos andurriales a buscar aventuras, divertíamos el trabajo de los caminos con gustosas y entretenidas conversaciones; yo le decía muchas verdades que le escocían, y él era tan discreto, que solía apreciarlas por su valor sin desazonarse. (p. 5) 
Y no mentía. El escudero demostraba sentir una admiración sin límites por su primer amo:

\begin{abstract}
Mi amo, que Dios haya, sabía más que los Frailes, y era capaz de subir a un púlpito, y convertir a los Moros y a los Judíos con sus palabras; pero enjamás le oí yo unas cosas tan desatinadas como son esas, bien que... si otro caballero más honrado que aquél y más buen cristiano... [...] Pero es de saber, que mi amo tenía más valentía en el corazón, y más deseo de honras y de grandeza en aquel pecho, que cuantos Herodes y cuantos Judas ha relatado V. M.: lo mismo embestía él con treinta o cuarenta gigantes que muchachos golosos con un plato de huevos moles, y así se entraba sólo y con su lanzón por un ejército de dos o tres millones de almas, como Santiago por los Moros, y esto no digistis, sino ogis vistis. (p. 10)
\end{abstract}

Habrá que notar que en este texto, aunque don Quijote es portador de un valor positivo, el autor no puede evitar identificarlo, aunque indirectamente, con Napoleón y su loca aventura en España, siguiendo las opiniones más generalizadas; en realidad en el opúsculo hay no uno, sino dos don Quijotes, el conocido por todos, el loco, el que sí podía compararse con Napoleón, y otro, el don Quijote auténtico, el garantizado por sancho Panza, y ése sí, perfectamente positivo en todo, inasimilable al corso aventurero. Seguramente sin proponérselo Meseguer se había cervantizado hasta el punto de recurrir a personajes de la novela para crear distintos planos de interpretación de otros personajes, para quijotizar a Napoleón.

De las palabras de Meseguer hay que aceptar que según él lo que se pensara de don Quijote habría de ser muy distinto de la opinión que mereciera Napoleón. Está menos claro si la misma convicción la sentía también Clemente Carnicero, pues desde el principio de su texto había dejado dicho (p. I, 5):

Los tiempos en que don Quijote anduvo por el mundo fueron felices, los presentes y venideros se tendrán por felicísimos, y aun serán envidiados de aquéllos, porque en éstos haya venido el gran Napoleón, que en el prurito de enderezar tuertos y cojos le puede dar quince y falta a nuestro gran manchego.

Aparentemente Napoleón sería un don Quijote con más éxito, si se consideran los resultados de sus actos, pero es evidente la intención satírica del texto. O, de lo contrario, sería preciso admitir que enderezar tuertos era, a los ojos del pensamiento conservador, una empresa risible, es decir, ponía en el mismo plano a Napoleón y al don Quijote bufón; aparecería de nuevo, como en Meseguer, la sombra de la duda sobre el sentido de luchar por la libertad y la justicia. Esta posibilidad interpretativa es muy interesante porque el libro devolvía a Napoleón la acusación que sus seguidores habían lanzado anteriormente, de

que el verdadero retrato de don Quijote eran el rey Jorge de Inglaterra, el lord Danig, y demás españoles que se lisonjeaban de poder contrarrestar 
el inmenso poder de Napoleón [...]. Tratar de Quijotes, fatuos, entusiastas, egoístas y fomentadores de una guerra tan sangrienta [...] sin más razón que su Quijotesco poder. (I, pp. 27-28)

En el metatexto político de Clemente Carnicero resulta evidente que la autenticidad del escudero tomaba su fuerza de ser del hecho de que en realidad encarnaba el símbolo del pueblo alzado contra el invasor. Leyéndolo, don Quijote aparece como marcado por una valoración negativa, pues al condenar la ambición napoleónica el autor se preguntaba

¿quiénes mejor pueden gloriarse de haber imitado a don Quijote? ¿Cuántos millares de tuertos, cojos, mancos y pupilos no han hecho sin necesidad, justicia y utilidad en lugar de enderezarlos y socorrerles?

Aquí la retórica y el sentido de la pregunta exigen que la respuesta, para condenar al Emperador, absuelva al Caballero de la Triste Figura, pues él sí hacía justicia, socorría a pupilos y enderezaba entuertos, pero entonces Napoleón no podía ser el vivo original de don Quijote, dado que los dos actuaban de manera diametralmente opuesta. Dificultades por otra parte de poca monta porque el libro no era un tratado de lógica sino una obra de partido. Lo que se pone de manifiesto son no sólo todas las ambivalencias al analizar la figura de don Quijote, sino también la práctica imposibilidad de hacer de él un instrumento de propaganda sin haber previamente establecido unívocamente su significado.

El otro texto propagandístico, el Diálogo, era exclusivamente político. Como se había formado ya lo que Sancho llamaba Cofradía Nacional, el texto intentaba animar a los patriotas a estar unidos ante el invasor:

SANCHO: la Patria se pondrá buena: porque miraremos de reojo todas las cosas francesas, seremos Españoles rancios, y Dios echará su gracia a borbotones sobre nosotros.

D. QUiJote: Pensabas bien: pues siguiendo pasos contrarios a los adoptados en Francia, es consecuencia necesaria lo uno y lo otro. (p. 2)

El tema de esta conversación se refería a un hecho de actualidad, la reunión en 1810 de la Cortes en Cádiz, cuyo nombre Sancho prevaricaba cómicamente. Lo corregía don Quijote, «Tente Sancho, que querrás decir Congreso Nacional y no Cofradía» y el escudero concluía: «Así es. Y llámese Conqueso, o como se quiera...» (pp. 1-2). Una asamblea donde la unidad patriótica era, a pesar de los deseos de amo y escudero, puramente nominal. Albert Dérozier ya hizo notar como, por el contrario, en esa Junta liberales y absolutistas se enfrentaron políticamente desde el primer momento ${ }^{22}$, entre otros asuntos en

22. Dérozier, Escritores políticos..., op. cit. pp. 24-28. Tierno Galván, Enrique, «Prólogo», Actas de las Cortes de Cádiz, Taurus, Madrid, 1964. La bibliografía sobre la Guerra de la Independencia es muy extensa. Entre las obras más recientes, consúltense Armillas Vicente, José Antonio, La Guerra de la Independencia, Zaragoza, Institución Fernando el Católico, 2001; «Conflicto y sociedad civil en la España napoleónica», Jornadas sobre la Batalla de Bailén y la España Contemporánea, Jaén, 
lo que se refería a la política religiosa, pero con la vista puesta en la propaganda no convenía marcar diferencias sino subrayar lo que unía. Tanto y más cuando el Diálogo estaba escrito para defender los intereses de la Iglesia.

Precisamente sobre ese punto versaba la discusión entre don Quijote y Sancho, pues el caballero aseguraba que ningún católico auténtico podía «lanzar sus tiros» contra «la Iglesia, sus Ministros, y sus Bienes» aun en momentos tan delicados como los de la guerra. Sancho estaba preocupado porque oía

que se echan chilindrinas, a los bienes de los Cleigos, [...] y aunque estas cosas las dicen así, así, y como de buena intención, yo digo, que anda niño con esas coles, calle madre que tinto lo traigo.

$\mathrm{Su}$ amo alertaba de que las insinuaciones anticlericales eran «los medios, de que se valió Voltaire contra la religión, disparándola sus tiros desde el Lago de Ginebra» y defendía la Iglesia y la ortodoxia tridentina (pp. 2-3). El discurso de Sancho, amén de sabroso, era más articulado, pues añadía:
Hay más, señor, que chillan contra los Cleigos y callan como unos putos, sobre los grandes Señores Mayorazgos gordos que gastan sus bienes en fachendas, en poner guapas sus hijas y en [...] aun peormente suelen gastarlos y lo callo por respeto a la andante caballería que vuesa merced profesa.

La desazón del simple escudero, aquí tomado como ejemplo del buen hijo de la Iglesia, se debía a que en el mismo Diálogo otro personaje cervantino, Sansón Carrasco, le había dicho que los religiosos sostenían la causa de la guerra mucho más que la aristocracia, y aunque don Quijote intentara defender a la nobleza, el escudero le ganaba por la mano y descalificaba a los aristócratas por tibios (p. 7); es ésta una crítica a los afrancesados, muchos de ellos pertenecientes a las clases sociales superiores. Entonces el caballero se rendía y se ponía a enumerar, alabándolas, las aportaciones que la Iglesia de España había hecho desde siempre en beneficio de la Corona y para el bienestar de los súbditos. Oyéndolo, Sancho no podía por menos que exclamar «¡Jesús! ¡Jesús! ¡Señor! Y creía yo (y conmigo todo mi lugar) que de cuantos diezmos se pagaban eran todos para el Señor Cura» tras lo cual abría los ojos al papel benefactor de la religión en el país (pp. 10-11), quod erat demonstrandum. El discurso ideológico de este diálogo y su sesgo evidente propagandístico acababa con una certificación del propio Cide Amete, quien añadía:

estoy pasmado, de que entre Católicos, se permita hablar de esta manera, de los Derviches Religiosos de los Imanes Curas: sin perdonar como he oído muchas veces, al que tiene por Vicario del sublime pastor, que da luz y guía, a los verdaderos creyentes. (p. 12) 
Esta era la convicción que se deseaba inculcar en el pueblo enfervorizado en la lucha contra el francés, fuertemente ideologizado y evidentemente dirigido por instancias tradicionalistas fácilmente reconocibles.

Desde el punto de vista de la falsificación propagandística lo que se debe subrayar en este Diálogo es el recurso mimético usado para componer el texto; los refranes que espolvorean el discurso de Sancho sirven para certificar la autenticidad del personaje, mientras que la atribución del opúsculo al mismísimo Cide Hamete es un guiño hacia los enterados a la vez que el supuesto marchamo de autenticidad del texto.

Salta pues a la vista la falta de unidad de criterios en el momento de elaborar un mensaje partiendo del personaje cervantino y la dificultad para quedarse con un modelo a carta cabal, como decía Clemente Carnicero (I, p. 28):

Napoleón no es el retrato, sino el vivo original de aquel don Quijote que con tanta gracia, amenidad y elegancia nos describió el inmortal Cervantes.

En los textos publicados durante la Guerra de la Independencia se identificaba físicamente a don Quijote y a Napoleón. Se puede ahora mencionar aquí, aunque brevemente, algunos ejemplos del mismo uso propagandístico de la novela cervantina o sus personajes en el primer tercio del siglo XIX, en la lucha política entre liberales y ultramontanos, en los que los segundos atacaban la modernidad encarnándola en la figura del caballero andante. El estudio de la interpretación de la novela cervantina en el Ochocientos no cabe en este artículo, pero dado el ínfimo nivel estético y cultural de los panfletos examinados, habrá que reconocer que éstos debían más a la tradición política inmediata que a la historia de la literatura. De hecho los escritos de los años veinte y treinta seguían la línea ya presente en varios de los textos antinapoleónicos, en los que la crítica de la invasión francesa se realizaba desde el punto de vista conservador y no liberal, con ataques a la Ilustración y alabanzas a la familia real española como elementos constantes. A lo que se apuntaba generalmente era a la base ideológica del liberalismo, que para los tradicionalistas coincidía con la filosofía moderna. Los escritores políticos conservadores en sus textos despreciaban la carga positiva del caballero andante en cuanto elemento de lucha patriótica tal y como se había querido presentar la Guerra de la Independencia y don Quijote entonces era el referente de una locura que había que combatir apelando a la tradición española y a la exégesis literaria:

Cuando el inmortal Cervantes se propuso sepultar en el olvido las leyendas caballerescas, no se ocultó a su talento extraordinario la dificultad o mejor diré imposibilidad que había de lograrlo por los medios ordinarios de la persuasión y convicción. Estos medios empleados ya por otros sin ningún resultado le hicieron conocer que no se debe apelar al raciocinio para desvanecer preocupaciones que rayan en delirios. Así es que su imaginación creadora le sugirió la grande idea de inventar un héroe que enfrascándose tanto en estas leyendas tomase al fin la resolución de marchar en busca de aventuras, tales, cuales había leído en sus disparatados libros de caballería 
[...]. Al ver circular en nuestros días una leyenda todavía más perjudicial, he hecho el ensayo de dar a luz otro Quijote a fin de desterrar de la sociedad por el mismo medio que Cervantes, tantos libros inmorales, doctrinas anárquicas y corrompidas, principios subversivos y elementos de desorden que tan profusamente se han esparcido por todo el mundo civilizado y difícilmente se cortará este daño si no se corta en su raíz.

No he tomado de la obra de Cervantes más que la idea. A su imitación supongo igualmente que otro héroe se aficionó tanto a la lectura de estos libros que dio en la extraña locura de emprender una regeneración universal [...]. Las aventuras del primero en nada se parecen a las de este último, sin embargo son características del siglo que se ha querido apellidar de las luces, luces que ofuscaron o más bien cegaron la luz de la razón de nuestro héroe ${ }^{23}$.

Así pensaba Siñériz, afirmando que tantos libros inmorales, doctrinas anárquicas y corrompidas, principios subversivos y elementos de desorden - léase progresismo - eran meras quijotadas. El mismo esfuerzo lo habían demostrado Navarro Gómez, para denunciar la Constitución y la destrucción de la religión y la moralidad pública, y Jiménez Cuenca y el Licenciado Tirteafuera ${ }^{24}$ con textos en los que se traía a la escena a un personaje grotesco y risible, que fácilmente se podía hacer el blanco de las burlas de los escritores. Sin embargo hay una importante diferencia entre la producción política de la Guerra de la Independencia, cuando don Quijote aparecía directamente como personaje del texto, y las obras de los antiliberales, en las que don Quijote no es mencionado sino en la medida en que es el ejemplo de una actitud inaceptable para las personas de bien. La razón de este hecho estriba en que entre 1808 y 1814 era posible personalizar al enemigo en un sujeto concreto, Napoleón Bonaparte, mientras que en los años treinta y cuarenta del siglo XIX la lucha era contra ideas políticas generales y no contra personas concretas por lo que no habría tenido sentido un don Quijote/Riego o don Quijote/Espartero.

La lectura de esos textos lleva a la conclusión de que para los escritores políticos conservadores del siglo XIX don Quijote no era una figura representativa de España y que, al contrario, el personaje encarnaba las novedades que había que rechazar por encima de todo. Se podría decir que era una especie de extravagancia moral totalmente rechazable, y en este sentido es posible vislumbrar una continuidad sustancial entre la posición antiliberal decimo-

23. Siñériz, Juan Francisco, El Quijote de la revolución, o historia de la vida, hechos y proezas de Monsieur Le Grand-Homme Pamparanuja, héroe politico, filósofo moderno, caballero andante, y reformador de todo el género humano. Obra escrita en beneficio de la humanidad por D. --- publicada en París en 1837 y traducida al español, 4 tomos, 2 vols., Barcelona, Valentín Torrás, 1841, I, 1, pp. VII-X.

24. Navarro Gómez, José María, Los dos Quijotes del siglo diez y nueve o sea Historia de las revoluciones de los Filósofos modernos en España: poema en cinco cantos, en que se refieren todos los sucesos que han intervenido para plantificar la llamada Constitución política de la Monarquía Española y para su abolición, Pamplona, Erausun y Rada, 1825. Otros títulos son Jiménez Cuenca, José, Respuesta a la frailada del Padre Clavellina transformado en D. Quijote de la Mancha, Córdoba, Mantué, 1843; Diarrea de las imprentas. Memoria sobre la epidemia de este nombre que reina actualmente en Cádiz, por el Doctor Pedro Recio de Tirteafuera, Cádiz, Viuda de Comes, 1811. 
nónica y la antinapoleónica de la Guerra de la Independencia, puesto que al enemigo se lo connotaba con la misma metáfora literaria, don Quijote de la Mancha, convertido en el compendio de todo lo que era la anti-España. Por cierto que se trata de una malhadada idea que tendría clamoroso éxito en los tiempos posteriores.

Así que se puede concluir que el uso político de la figura literaria cervantina implicaba una doble incomprensión: primero, la lectura en clave simplemente burlesca del personaje de la novela, y, segundo, la incomprensión de sus profundísimas raíces en la tradición y la cultura popular de la Península ${ }^{25}$.

Mas desde el punto de vista político/literario, lo que hay que subrayar es que, cuando don Quijote servía para defender las opiniones de los patriotas antinapoleónicos, se lo presentaba cual figura positiva, invirtiendo los términos de la valoración del Dieciocho, según la cual el caballero aparecía casi universalmente como figurón risible. Este uso sin prejuicios del personaje cervantino es tanto más cierto cuando en dos autores las intenciones políticas coinciden, pero uno pretende criticar al invasor y el otro alabar al patriota; así ocurría en Meseguer y en Clemente. Sin embargo la construcción crítica de don Quijote en los opúsculos de propaganda es más compleja, rica, pues en el mismo texto se pueden llegar a contraponer dos imágenes y dos valoraciones distintas del mismo personaje.

Así la figura de don Quijote que se usó con valor ideológico en el siglo XIX, durante la Guerra de la Independencia primero y en las diatribas antiliberales más tarde, participaba de una doble y enfrentada naturaleza y en la Guerra del Francés el Caballero de la Triste Figura a veces representaba un papel completamente negativo - personificaba a Napoleón - mientras que en ocasiones por el contrario era ejemplo de virtudes - y representaba por lo mismo lo opuesto que el Emperador, que los ilustrados y en general que el progreso-. El uso político y propagandístico sufrió después una evolución definitiva puesto que en los escritos antiliberales de los años 20 y 30 su función era ya completamente negativa.

Recibido: 18-09-2008

Aceptado: 24-07-2009

25. «El universal ideal quijotesco llegó a hacerse carne en la realidad del pueblo español mucho más de lo que pudo ser en la centuria anterior cuando nació el personaje». Rodríguez Cepeda, Enrique, «Los Quijotes del siglo XVIII», op. cit., pp. 752-779. 


\title{
Resumen
}

En 1808 algunos escritores políticos recurrieron a la figura de don Quijote para escribir unos opúsculos patrióticos en los que se comparaba a Napoleón y al Caballero manchego. Analizando esos textos se puede observar la ambivalencia del significado del personaje cervantino porque se lo consideraba a veces positivo y en otras ocasiones cargado de connotaciones negativas, por lo que la crítica a Napoleón se construía, según los casos, con la identificación o la oposición total de las dos figuras.

Palabras clave: Don Quijote. Napoleón. Propaganda. Guerra de la Independencia.

Title: Don Quixote and the Peninsular war

\begin{abstract}
In 1808 some political writers appealed to the character of Don Quixote in order to write patriotic libels in which Napoleon was compared to the Knight from La Mancha. The analysis of those texts will show the ambiguity of the meaning of Cervantes's creature, as it was sometimes thought to be a positive character, whereas in other occasions it was seen as the bearer of negative connotations. Thus criticism to Napoleon was built, according to different cases, on the identification or the opposition of the two figures.
\end{abstract}

Key words: Don Quixote. Napoleon. Propaganda. Peninsular War. 